\title{
FRAKSINASI PEPTIDA DARI HIDROLISAT PROTEIN IKAN SELAR (Selaroides leptolepis)
}

\author{
Reinal Putalan ${ }^{1 *}$, Tati Nurhayati ${ }^{2}$, Ekowati Chasanah ${ }^{3}$ \\ ${ }^{1}$ Politeknik Palu, Jalan Sinar Kemuning 1 Nomor 1 A Bumi Roviga Tondo-Palu Sulawesi Tengah \\ ${ }^{2}$ Departemen Teknologi Hasil Perairan, IPB University, Jalan Agatis, Kampus IPB Dramaga, Bogor \\ ${ }^{3}$ Balai Besar Riset Pengolahan Produk dan Bioteknologi Kelautan dan Perikanan Jakarta \\ ${ }^{*}$ Korespondensi: reinalputalan@gmail.com \\ Diterima: 18 Agustus 2020/Disetujui: 04 November 2020
}

Cara sitasi: Putalan R, Nurhayati T, Chasanah E. 2020. Fraksinasi peptida dari hidrolisat protein ikan selar (Selaroides leptolepis). Jurnal Pengolahan Hasil Perikanan Indonesia. 23(3): 434-440.

\begin{abstract}
Abstrak
Ikan selar (Selaroides leptolepis) merupakan ikan dengan sebaran yang cukup luas dengan produksi yang melimpah serta memiliki kandungan gizi protein yang tinggi. Peptida yang berasal dari hidrolisat protein ikan mempunyai manfaat yang besar untuk pengembangan produk pangan fungsional. Penelitian ini bertujuan mendapatkan fraksi yang memiliki aktivitas antioksidan dan inhibitor ACE dari hidrolisat protein ikan selar. Penelitian dilakukan dengan cara melakukan fraksinasi peptida menggunakan kolom kromatografi, lalu dikarakterisasi. Hasil penelitian menunjukkan bahwa fraksinasi dengan kolom kromatografi filtrasi gel mendapatkan 2 fraksi, yaitu fraksi A dan B dengan IC $_{50}$ berturut-turut 4.737,95 ppm dan 529,42 ppm, serta memiliki aktivitas inhibitor ACE sebesar 90,65\% dan 96.61\%. Peptida fraksi B lebih potensial sebagai antioksidan dan inhibitor ACE.
\end{abstract}

Kata kunci: antioksidan, inhibitor ACE, kromatografi gel filtrasi, peptida

\section{Fractionation of Peptide from Yellowstripe scad (Selaroides leptolepis) Protein Hydrolysate}

\begin{abstract}
Yellowstripe scad (Selaroides leptolepis) is a highly produced fish, widely distribute along Indonesian coast and has high protein nutritional content. Peptides derived from fish protein hydrolysate have great benefits for the development of function-al food products. This study was aimed to obtain the peptide fraction from yellowstripe scad protein hydrolysate having anti-oxidant and ACE inhibitor activity. The research was conducted by fractionating the peptides using a chromatography column. The results showed that the fractionation resulted 2 fractions, namely fractions A and B with $\mathrm{IC}_{50} 4,737.95 \mathrm{ppm}$ and $529.42 \mathrm{ppm}$ and ACE inhibitor activity of $90.65 \%$ and $96.61 \%$, respectively. Peptide fraction B had higher antioxidants and ACE inhibitors than that of fraction A.
\end{abstract}

Keywords: ACE inhibitors, antioxidants, filtration gel chromatography, peptides

\section{PENDAHULUAN}

Ikan selar (Selaroidesleptolepis) merupakan ikan dengan sebaran yang cukup luas dengan produksi yang melimpah serta memiliki kandungan gizi protein yang tinggi. Protein pada makanan dari ikan telah lama dikenal karena nilai gizi dan sifat fungsionalnya. Nilai gizi dan sifat fungsional dari protein memiliki keterkaitan dengan kandungan peptida serta asam aminonya sehingga untuk mendapatkan sifat fungsional antioksidan dan inhibitor
ACE dari protein ikan selar perlu dilakukan proses hidrolisis.

Hidrolisat proteinikan adalah produkyang didapatkan dari penguraian atau pemotongan protein menjadi peptida sederhana dan asam amino melalui proses hidrolisis oleh enzim, asam maupun basa. Peptida bioaktif adalah fragmen pendek protein dengan residu asam amino 2-20 yang memiliki fungsi spesifik, misalnya antiinflamasi, antioksidan, antihipertensi, antimikroba, dan antikanker (Ryan et al. 2011). 
Sejumlah penelitian menjelaskan bahwa peptida yang berasal dari hidrolisat protein secara enzimatik baik ikan maupun dari protein hewani lain memiliki aktivitas sebagai antioksidan (Jun et al. 2004; Fan et al. 2012) dan juga sebagai inhibitor ACE (Wu et al. 2015). Hasil penelitian Klompong et al. (2009) menunjukkan bahwa peptida ikan selar memiliki aktivitas antioksidan 80\%, Ji et al. (2013) menghidrolisis ikan croaker kuning menghasilkan peptida yang memiliki aktivitas antioksidan dengan $\mathrm{IC}_{50} 1.784 \mathrm{ppm}$. Khirzin et al. (2015) menghidrolisis teripang secara enzimatis menghasilkan peptida dengan aktivitas inhibitor ACE 82,31\%. Toopcham et al. (2017) mendapatkan peptida dari tilapia dapat menghambat kerja enzim ACE 89,3\%. Putalan et al. (2018) menghidrolisis ikan selar menggunakan enzim protease koleksi BBRP2BKP menunjukkan hidrolisat protein ikan selar memiliki aktivitas antioksidan dan inhibitor ACE. Tujuan penelitian ini adalah mendapatkan fraksi yang memiliki aktivitas antioksidan dan inhibitor ACE dari hidrolisat protein ikan selar.

\section{BAHAN DAN METODE Bahan dan Alat}

Bahan penelitian yang digunakan meliputi daging ikan selar yang diperoleh dari pasar ikan Muara Baru, dengan panjang 12-17 cm, enzim protease lokal koleksi BBRP2BKP, angiotensin converting enzyme (Sigma, AS), 2,2-diphenyl1-picrylhydrazyl (Sigma, AS). Peralatan yang digunakan yaitu spektrofotometer (Thermo Scientific ${ }^{\text {Tit }}$ Multiskan ${ }^{\text {Th }}$ GO Microplate Spectrophotometer, Singapura), ultrafiltrasi (GE Healthcare QuixStand benchtop system, AS), gel filtrasi $9,9 \mathrm{~mm} \times 30 \mathrm{~cm}$.

\section{Metode Penelitian}

\section{Fraksinasi menggunakan kromatografi gel filtrasi}

Peptida berukuran 5-3 kDa difraksinasi menggunakan kromatografi gel filtrasi dengan matrik Sephadex G-25 superfine (Ge Healthcare) yang mampu memisahkan protein dengan kisaran berat molekul 1-5 $\mathrm{kDa}$. Ukuran kolom yang digunakan adalah $9,9 \mathrm{~mm} \times 30 \mathrm{~cm}$. Sebanyak $1,5 \mathrm{~mL}$ sampel dimasukkan ke dalam kolom dan dielusi menggunakan akuades. Sampel dipantau pada panjang gelombang $280 \mathrm{~nm}$. Ukuran fraksi yang digunakan sebesar $3 \mathrm{~mL}$ per tabung. Eluat dalam tabung dari peak-peak yang muncul dikumpulkan menjadi fraksifraksi. Fraksi yang diperoleh selanjutnya diukur absorbansinya pada $\lambda=280 \mathrm{~nm}$, kadar protein (Lowry et al. 1951), kadar peptida aktivitas antioksidan (Li et al. 2006) dan inhibitor ACE (Nakamura et al. 1995) serta analisis komposisi asam amino menggunakan EZ:faast-Free (physiological) Amino Acid Analysis by GC-FID.

\section{Kadar Protein (Lowry et al. 1951)}

Pengukuran kadar protein terlarut hidrolisat ditentukan dengan metode Lowry menggunakan bovine serum albumin (BSA) sebagai protein standar. Tahapan analisis dimulai dengan pembuatan kurva standar protein pada seri konsentrasi BSA pada konsentrasi 0, 20, 40 80, 100 ppm, sedangkan larutan lowry merupakan pencampuran dari larutan alkali, ion tembaga dan 10 $\mathrm{Na}_{2}$ (tartrat)2 $\left(\mathrm{H}_{2} \mathrm{O}\right)$ dengan konsentrasi yang sudah diketahui. Setelah proses dilakukan sampel ditambahkan folin. Campuran diukur absorbansinya pada panjang gelombang maksimum $(750 \mathrm{~nm})$.

\section{Kadar Peptida (Church et al. 1983)}

Analisis kandungan peptida diukur dengan metode Church et al. (1983) dengan beberapa modifikasi. Reagen O-pthalaldehyde (OPA) segar sebanyak $50 \mathrm{~mL}$ disiapkan dengan cara mencampur $25 \mathrm{~mL}$ dari $100 \mathrm{mM}$ sodium tetra hidroborat; $2,5 \mathrm{~mL}$ dari $20 \%$ (w/w) sodium dodecyl sulphate (SDS), $40 \mathrm{mg}$ larutan OPA (dilarutkan dalam $1 \mathrm{~mL}$ metanol) dan $100 \mathrm{~mL} \beta$-merkaptoetanol. Campuran kemudian diencerkan hingga $50 \mathrm{~mL}$ dengan air deionisasi. Sebanyak $50 \mu \mathrm{L}$ sampel, dicampur dengan $2 \mathrm{~mL}$ reagen OPA dan diinkubasi selama 2 menit pada suhu ruang. Absorbansi diukur pada $340 \mathrm{~nm}$ menggunakan spektrofotometer. Kasein tripton dalam bufer fosfat $(\mathrm{pH} \mathrm{7,4)}$ digunakan sebagai standar untuk menghitung kandungan peptida. 
Aktivitas Antioksidan (Li et al. 2002)

Analisis aktivitas antioksidan menggunakan radikal bebas DPPH. Sampel dibuat dalam seri konsentrasi (ppm) yang telah ditentukan, tiap seri konsentrasi dimasukkan ke dalam sumur microplate sebanyak 160 $\mu \mathrm{L}$, kemudian ditambahkan larutan DPPH masing-masing $40 \mu \mathrm{L}$. Larutan DPPH dibuat dengan cara melarutkan $3 \mathrm{mg}$ DPPH ke dalam $10 \mathrm{~mL}$ metanol p.a. Blangko sampel dibuat dengan cara $160 \mu \mathrm{L}$ sampel dimasukkan ke dalam sumur lalu ditambahkan $40 \mu \mathrm{L}$ metanol p.a. Kontrol negatif dibuat dengan cara $160 \mu \mathrm{L}$ metanol p.a ditambahkan dengan $40 \mu \mathrm{L}$ DPPH dan sebagai blangko digunakan $200 \mu \mathrm{L}$ metanol p.a. vitamin $\mathrm{C}$ digunakan sebagai kontrol positif dengan seri konsentrasi yang telah ditentukan. Selanjutnya microplate diinkubasi pada suhu ruang selama 30 menit dan dibaca absorbansinya dengan spektrofotometer UV-Vis pada panjang gelombang $517 \mathrm{~nm}$. Persen aktivitas penghambatan radikal bebas dihitung dengan rumus:

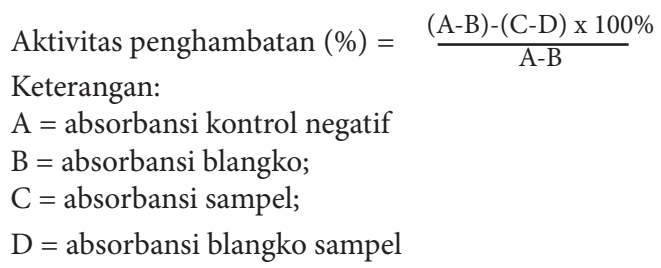

Persen aktivitas penghambatan yang didapat kemudian diplotkan ke dalam kurva regresi linier dengan sumbu $\mathrm{x}$ berupa konsentrasi dan sumbu y berupa persen penghambatan. Nilai inhibition concentration $50\left(\mathrm{IC}_{50}\right)$ didapat dengan memasukkan angka 50 ke dalam sumbu y dan hasil $\mathrm{IC}_{50}$ sampel dibandingkan dengan $\mathrm{IC}_{50}$ dari standar.

\section{Aktivitas inhibitor ACE (Nakamura et al. 1995)}

Aktivitas penghambat angiotensin converting enzyme (ACE) diukur berdasarkan laju pembentukan asam hippurat dari hippuryl-L-histidyl-L-leusine(HHL). Kaptopril digunakan sebagai kontrol positif. Sampel $50 \mu \mathrm{L}(10 \mathrm{mg} / \mathrm{mL})$ ditambah 125 bufer substrat $(7,6 \mathrm{mM}$ HHL dan $608 \mathrm{mM} \mathrm{NaCl}$ dalam $10 \mathrm{~mL}$ bufer borat $\mathrm{pH} 8,3$ ) campuran diinkubasi pada suhu $37^{\circ} \mathrm{C}$ selama 15 menit. Selanjutnya $50 \mu \mathrm{L}$ enzim ACE $50 \mathrm{mU} / \mathrm{mL}$ ditambahkan pada campuran kemudian diinkubasi selama 30 menit. Reaksi dihentikan dengan penambahan $200 \mu \mathrm{L} \quad \mathrm{HCl} 1 \mathrm{~N}$. Campuran di-vortex, ditambah dengan 1.140 $\mu \mathrm{L}$ etil asetat kemudian disentrifugasi 10.000 $\mathrm{x} g$ selama 10 menit. Supernatan sebanyak $800 \mu \mathrm{L}$ diambil dan dikeringkan pada suhu $95{ }^{\circ} \mathrm{C}$ selama 90 menit. Asam hirupat yang terbentuk dilarutkan ke dalam $1 \mathrm{~mL}$ akuabides. Absorbansi diukur pada panjang gelombang $228 \mathrm{~nm}$ menggunakan spektro UV-Vis. Perhitungan aktivitas antihipertensi dengan penghambat ACE yaitu sebagai berikut:

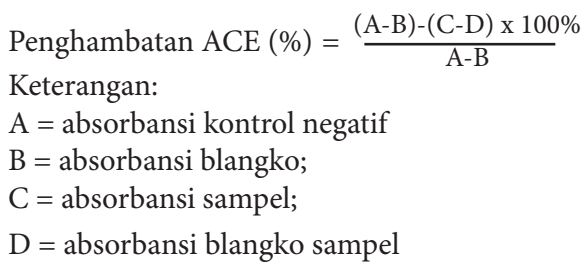

\section{Asam Amino (EZ:faast)}

Komposisiasam aminoditentukan dengan menggunakan EZ:faast-Free (physiological) Amino Acid Analysis dari GC-FID. Analisis ini terdiri dari tiga tahap, yaitu tahap pembuatan hidrolisat protein, tahap preparasi sampel dan tahap injeksi serta analisis asam amino.

a. Tahap pembuatan hidrolisat protein

Preparasi sampel, yaitu tahap pembuatan hidrolisat protein, sampel ditimbang, sebanyak 200 mg. Sampel tersebut ditambahkan HCl 6 $\mathrm{N}$ sebanyak $10 \mathrm{~mL}$ yang kemudian dipanaskan dalam microwave pada suhu $110{ }^{\circ} \mathrm{C}$ selama 80 menit. Pemanasan dilakukan untuk mempercepat reaksi hidrolisis.

b. Tahap preparasi sampel

Sampel hasil hidrolisis selanjutnya dipreparasi kembali menggunakan kit yang tersedia.

c. Tahap injeksi ke GC

Hasil preparasi diambil sebanyak $100 \mu \mathrm{L}$ untuk diinjeksikan ke dalam GC. Perhitungan konsentrasi asam amino yang ada pada bahan dilakukan dengan pembuatan kromatogram standar dengan menggunakan asam amino yang telah siap dipakai yang mengalami perlakuan yang sama dengan sampel. Untuk analisis kuantitatif dapat dihitung dengan cara:

Asam Amino $(\mathrm{ng} / \mathrm{mL})=\frac{\text { luas area sampel } \mathrm{x}(\text { luas area standar } \mathrm{x} \text { berat molekul) }}{\text { luas area standar }}$ 
Pengaturan GC-FID

Injeksi Split 1:15@250 ${ }^{\circ} \mathrm{C}, 2.0 \mu \mathrm{L}$

Carrier Gas Helium, $1.5 \mathrm{~mL} / \mathrm{min}$ constant flow

Oven Program $32^{\circ} \mathrm{C} / \mathrm{min}$ for 110 to $320^{\circ} \mathrm{C}$

\section{Analisis Data}

Data yang diperoleh dianalisis menggunakan microsoft excel dan perangkat lunak SPSS versi 16 untuk mengetahui rata-rata dan standar deviasinya.

\section{HASIL DAN PEMBAHASAN}

Ukuran panjang peptida diduga memiliki kaitan erat dengan bioaktivitasnya. Beberapa penelitian menujukkan bahwa panjang peptida yang diisolasi dengan kromatografi gel filtrasi (Sephadex G-25) berpengaruh signifikan terhadap bioaktivitasnya (Sampath Kumar et al. 2011).Hasil kromatografi (Figure 1) menunjukkan bahwa peptida yang diisolasi menggunakan kromatografi gel filtrasi terdapat dua fraksi, fraksi A dan fraksi B.

Kromatografi filtrasi gel yang dilakukan menggunakan matrik Sephadex G-25, memiliki karakteristik memisahkan sampel berdasarkan berat molekul. Sampel dengan berat molekul lebih besar akan keluar lebih dahulu dan selanjutnya menjadi fraksi A, sedangkan sampel dengan berat molekul lebih kecil sementara tertahan pada matrik dan keluar belakangan dan menjadi fraksi B. Hal ini yang menyebabkan fraksi yang keluar lebih awal memiliki berat dan konsentrasi protein dan peptida yang lebih besar (Table1).

Hasil penelitian menunjukkan bahwa $\mathrm{IC}_{50}$ antioksidan fraksi B lebih kuat dibandingkan dengan fraksi A. Perbedaan bioaktivitas antar fraksi disebabkan oleh beberapa hal di antaranya adalah berat molekul dan komposisi asam amino (Zou et al. 2016). Peptida dengan berat molekul rendah $(<10 \mathrm{kDa})$ diketahui sebagai peptida antioksidan dan antihipertensi (Waseem et al. 2018). Nilai $\mathrm{IC}_{50}$ antioksidan hidrolisat protein yang difraksinasi menggunakan gel filtrasi matrik Sephadex G-25 memiliki nilai yang hampir sama (Fan et al. 2012 dan Mendis et al. 2005).

Inhibitor ACE pada fraksi B memiliki aktivitas $96,61 \%$ dan fraksi A 90,65\%. Beberapa peneliti menjelaskan peptida hasil hidrolisis protein dan diisolasi menggunakan metode gel filtrasi memiliki bioaktivitas sebagai inhibitor ACE. Sun et al. (2011) menyatakan bahwa peptida dari kerang air tawar yang

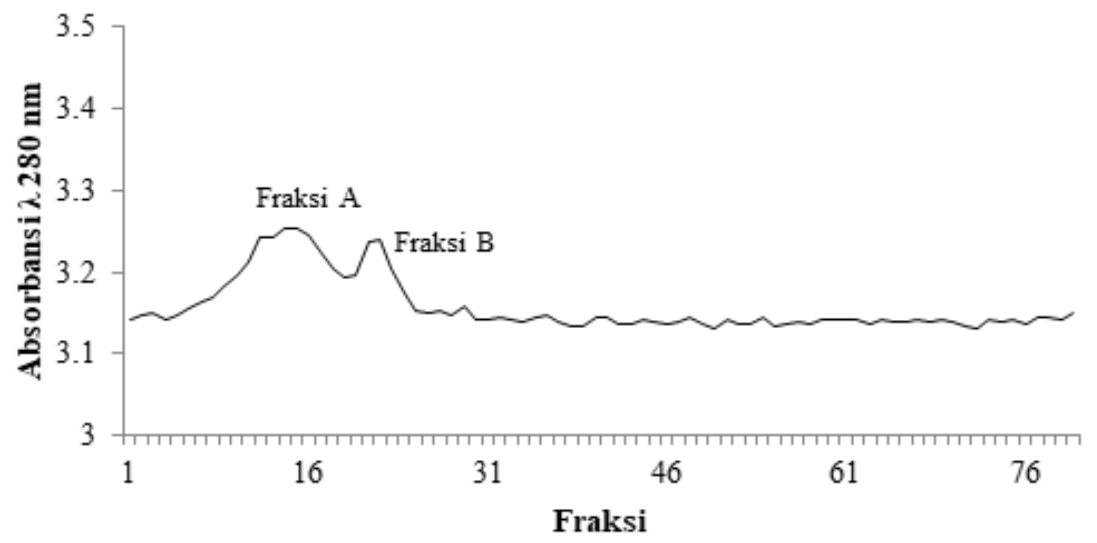

Figure 1 Gel filtration chromatography of peptide fraction(Sephadex G-25)

Table 1 Antioxidant activity and ACE inhibitor from filtration gel chromatography peptide fraction

\begin{tabular}{lccrrr}
\hline & Sample & $\begin{array}{c}\text { Peptide } \\
(\mathrm{mg} / \mathrm{mL})\end{array}$ & $\begin{array}{c}\text { Protein } \\
(\mathrm{mg} / \mathrm{mL})\end{array}$ & $\begin{array}{c}\mathrm{IC}_{50} \text { Antioxidant } \\
(\mathrm{ppm})\end{array}$ & $\begin{array}{c}\text { ACE Inhibitor } \\
(\%)\end{array}$ \\
\hline Gel & Fraction A & $60.96 \pm 0.24$ & $2.36 \pm 0.00$ & $4,737.95$ & $90.65 \pm 0.81$ \\
Filtration & Fraction B & $24.61 \pm 0.01$ & $0.44 \pm 0.03$ & 529.42 & $96.61 \pm 2.42$ \\
Control & Vit. C & - & - & 10.90 & - \\
$(+)$ & Captopril & - & - & - & 95.93 \\
\hline
\end{tabular}


diisolasi menggunakan gel filtrasi (Sephadex G-25) memiliki inhibitor ACE 67,23\%. Selanjutnya Zhang et al. (2018) menyatakan bahwa peptida dari gonad ubur-ubur yang diisolasi menggunakan gel filtrasi (Sephadex G-25) memiliki inhibitor ACE $80 \%$. Hasil penelitian menunjukkan bahwa terdapat perbedaan kandungan asam amino yang terdapat pada masing-masing fraksi. Kandungan asam amino dapat dilihat pada Table 2.

Hubungan antara berat molekul, komposisi dan urutan asam amino memengaruhi bioaktivitas baik antioksidan maupun inhibitor ACE (Kristinsson dan Raghavan 2014). Fraksi B memiliki bioaktivitas sebagai antioksidan serta inhibitor ACE yang kuat. Komposisi dari asam amino, misalnya valina, metionina, dan triptofan, yang cukup banyak pada fraksi B berpengaruh pada bioaktivitas sebagai antioksidan dan inhibitor ACE. Studi Nwachukwu dan Aluko (2019) serta Sarmadi dan Ismail (2010) menjelaskan bahwa komposisi asam amino tertentu yang terkandung pada suatu peptida, misalnya leusina atau valina, di daerah terminal- $\mathrm{N}$, asam amino yang mengandung sulfur nukleofilik (sisteina dan metionin), residu asam amino aromatik (fenilalanina, triptofan, dan tirosina) memberikan pengaruh yang signifikan pada bioktivitasnya. Data hasil penelitian juga diketahui mengandung asam amino alanina, valina, fenilalanina, leusina, metionina, prolina, tirosina, asparagin, aspartat, hidroksiprolina. Berdasarkan hasil studi
Mendis et al. (2005) diketahui bahwa peptida dari hidrolisat protein yang mengandung beberapa asam amino, misalnya alanina, valina, leusina, tirosina, metionina, histidina, triptofan, lisina, dan prolina, yang berfungsi sebagai antioksidan. Hasil studi Jao et al. (2012) menunjukkan bahwa peptida hasil hidrolisis protein yang mengandung asam amino contohnya triptofan, tirosina, fenilalanina, dan prolina memiliki aktivitas sebagai inhibitor ACE kuat. Berdasarkan hasil studi Je et al. (2005) diketahui bahwa peptida dengan residu asam amino tirosina dan dengan berat molekul yang kecil memiliki bioaktivitas antioksidan lebih kuat dibandingkan dengan yang lain.

\section{KESIMPULAN}

Peptida yang diisolasi dari hidrolisat protein ikan selar menggunakan metode kromatografi gel filtrasi memiliki aktivitas antioksidan dan inhibitor ACE. Peptida tersebut menunjukan aktivitas sebagai antioksidan $\left(\mathrm{IC}_{50} 529,42 \mathrm{ppm}\right.$ ) dan inhibitor ACE (96,61\%), dengan komposisi asam amino yang terdeteksi yaitu alanina, valina, leusina, prolina, asparagina, metionina, fenilalanina, ornitina dan tirosina. Peptida yang diisolasi dari hidrolisat protein ikan selar dapat diterapkan sebagai bahan makanan fungsional, suplemen atau bahkan obat-obatan.

\section{UCAPAN TERIMA KASIH}

Terima kasih disampaikan kepada Balai Besar Riset Pengolahan Produk dan

Table 2 Amino acid composition of peptide fraction separated using filtration gel chromatography

\begin{tabular}{ccccccccccr}
\hline $\begin{array}{c}\text { Amino acid } \\
(\%)\end{array}$ & Ala & Val & Phe & Ile & Leu & Met & Pro & Ser & Tyr & Gly \\
\hline Fraction A & 9.20 & 5.32 & 10.45 & 4.06 & 11.58 & 4.57 & 16.69 & 2.80 & 2.02 & 7.05 \\
Fraction B & 2.54 & 8.85 & 7.12 & - & 4.31 & 11.45 & 10.6 & - & 24.51 & - \\
\hline
\end{tabular}

Table 2 continued

\begin{tabular}{cccrrrrr}
\hline $\begin{array}{c}\text { Amino acid } \\
(\%)\end{array}$ & Asn & Asp & Lys & Hyp & Orn & AABA $^{*}$ & BAIBA $^{*}$ \\
\hline Fraction A & 2.68 & 7.81 & 3.63 & 5.00 & 5.79 & 1.36 & - \\
Fraction B & 9.26 & 8.27 & - & 3.29 & - & 3.57 & 6.23 \\
\hline
\end{tabular}

Note: AABA: $\alpha$-Aminobutyric acid; BAIBA: $\beta$-Aminoisobutyric acid 
Bioteknologi Kelautan dan Perikanan, Badan Riset dan SDM Kelautan dan Perikanan yang telah mengizinkan penulis ikut dalam proyek penelitian APBN 2016 di bawah supervisi Prof. Dr. Ekowati Chasanah. Selain itu, masing-masing penulis memiliki kontribusi yang sama dalam penyelesaian manuskrip ini.

\section{DAFTAR PUSTAKA}

Church FC, Swaisgood HE, Porter DH, Catignani GL. 1983. Spectrophotometric assay using o-Phthaldialdehyde for determination of proteolysis in milk and isolated milk proteins. Journal of Dairy Science. 66(6): 1219-1227.

Fan J, He J, Zhuang Y, Sun L. 2012. Purification and identification of antioxidant peptides from enzymatic hydrolysates of tilapia (Oreochromis niloticus) frame protein. Molecules. 17(11): 12836-12850.

Jao CL, Huang SL, Hsu KC. 2012. Angiotensin I-converting enzyme inhibitory peptides: Inhibition mode, bioavailability, and antihypertensive effects. BioMedicine. 2(4): 130-136.

Je JY, Park PJ, Kim SK. 2005. Antioxidant activity of a peptide isolated from alaska pollack (Theragra chalcogramma) frame protein hydrolysate. Food Research International. 38(1): 45-50.

Ji Y, Zhang G, Li X, Zhao B, Zhou S. 2013. Enzymatic hydrolysis of protein from small yellow croaker (Pseudosciaena polyactis) and evaluation of its antioxidant activity. Journal of Food Biochemistry. 37(3): 278-285.

Jun SY, Park PJ, Jung WK, Kim SK. 2004. Purification and characterization of an antioxidative peptide from enzymatic hydrolysate of yellowfin sole (Limanda aspera) frame protein. European Food Research and Technology. 219(1): 20-26.

Khirzin MH, Sukarno S, Yuliana ND, Fawzya YN, Chasanah E. 2015. Aktivitas inhibitor enzim pengubah angiotensin (ACE) dan antioksidan peptida kolagen dari teripang gama (Stichopus variegatus). Jurnal Pascapanen dan Bioteknologi Kelautan dan Perikanan. 10(1): 27.

Klompong V, Benjakul S, Yachai $M$, Visessanguan W, Shahidi F, Hayes KD.
2009. Amino acid composition and antioxidative peptides from protein hydrolysates of yellow stripe trevally (Selaroides leptolepis). Journal of Food Science. 74(2):126-133.

Li Y, Li X, Lee U, Jung SK, Hong DC, Byeng WS. 2006. A new radical scavenging anthracene glycoside, asperflavin ribofuranoside, and polyketides from a marine isolate of the fungus Microsporum. Chemical and Pharmaceutical Bulletin. 54(6): 882-883.

Lowry OH, Rosebrough NJ, Farr AL, Randall RJ. 1951. Protein measurement with the folin phenol reagent. The Journal of Biological Chemistry. 193(1): 265-275.

Mendis E, Rajapakse N, Byun HG, Kim SK. 2005. Investigation of jumbo squid (Dosidicus gigas) skin gelatin peptides for their in vitro antioxidant effects. Life Sciences. 77(17): 2166-2178.

Nakamura Y, Yamamoto N, Sakai K, Okubo A, Yamazaki S, Takano T. 1995. Purification and characterization of angiotensin I-converting enzyme inhibitors from sour milk. Journal of Dairy Science. 78(4): 777-783.

Nwachukwu ID, Aluko RE. 2019. Structural and functional properties of food proteinderived antioxidant peptides. Journal of Food Biochemistry. 43(1): 12761.

Putalan R, Munifah I, Nurhayati T, Chasanah E. 2018. Antioxidant and ace inhibitor potential of stripe trevally fish (Selaroides leptolepis) hydrolysate. Squalen Bulletin of Marine and Fisheries Postharvest and Biotechnology. 13(1): 17-22.

Ryan JT, Ross RP, Bolton D, Fitzgerald GF, Stanton C. 2011. Bioactive peptides from muscle sources: Meat and fish. Nutrients. 3(9): 765-791.

Sampath Kumar NS, Nazeer RA, Jaiganesh R. 2011. Purification and biochemical characterization of antioxidant peptide from horse mackerel (Megalaspis cordyla) viscera protein. Peptides. 32(7): 14961501.

Sarmadi BH, Ismail A. 2010. Antioxidative peptides from food proteins: A review. Peptides. 31(10): 1949-1956.

Soottawat B, Suthasinee Y, Theeraphol S, 
Sigrun MH, Kristinsson HG. 2014. Fish protein hydrolysates: production, bioactivities, and applications. Dalam: Antioxidants and Functional Components in Aquatic Foods. Kristinsson HG (editor). Chichester (EN): John Wiley \& Sons, Ltd. Sun Y, Hayakawa S, Ogawa M, Naknukool S, Guan Y, Matsumoto Y. 2011. Evaluation of angiotensin I-converting enzyme (ACE) inhibitory activities of hydrolysates generated from byproducts of freshwater clam. Food Science and Biotechnology. 20(2): 303-310.

Toopcham T, Mes JJ, Wichers HJ, Roytrakul S, Yongsawatdigul J. 2017. Bioavailability of angiotensin I-converting enzyme (ACE) inhibitory peptides derived from Virgibacillus halodenitrificans SK1-3-7 proteinases hydrolyzed tilapia muscle proteins. Food Chemistry. 220: 190-197.
Waseem M, Kumar S, Kumar A. 2018. Bioactive peptides. Dalam: Secondary Metabolite and Functional Food Components: Role in Health and Disease. Kumar S (editor). Punjab (ID): Nova Science Publishers.

Wu S, Feng X, Lan X, Xu Y, Liao D. 2015. Purification and identification of Angiotensin-I converting enzyme (ACE) inhibitory peptide from lizard fish (Saurida elongata) hydrolysate. Journal of Functional Foods. 13: 295-299.

Zhang Q, Song C, Zhao J, Shi X, Sun M, Liu J, Fu Y, Jin W, Zhu B. 2018. Separation and characterization of antioxidative and angiotensin converting enzyme inhibitory peptide from jellyfish gonad hydrolysate. Molecules. 23 (1): 94.

Zou T Bin, He TP, Li H Bin, Tang HW, Xia EQ. 2016. The structure-activity relationship of the antioxidant peptides from natural proteins. Molecules. 21(1):72. 